\title{
THE PROPOSED UNIFORM [?] COMMERCIAL CODE SHOULD NOT BE ADOPTED
}

\author{
FREDERIGK K, BEUTEL $\dagger$
}

THE American Law Institute and the Commissioners on Uniform Laws at their joint meeting in connection with the American Bar Association last fall finally approved the text of the Uniform Commercial Code, ${ }^{1}$ which is an attempt to codify within one unit the heart of the entire commercial law of the United States. The much heralded act is now ready for adoption by the various state legislatures.

As has been indicated in detail elsewhere, ${ }^{2}$ measured by the area it seeks to control, this is probably the most ambitious piece of codification undertaken in this country during the century. Although the process of drafting has taken six or seven years, considering the monumental size of the task and the preoccupation of the draftsman with other work, ${ }^{3}$ a period of twice that time by a full time staff would not have been too long. ${ }^{4}$ It has been hurriedly drafted and relentlessly pushed through the American Law Institute and the Commission on Uniform Laws with very little real consideration by the members of the bodies involved. Although the Code also carries the prestige of these two great organizations as also indicated elsewhere, ${ }^{\mathbf{5}}$ it has not had the quality of draftsmanship or diligent consideration with which the American Law Institute Restatements were compiled. There also has been little or no impartial research into the economic needs of the business community which the Code attempts to regulate in detail. The effect of this sort of authorship and procedure on Article 4 of the Code will be discussed in detail herein.

†Professor of Law, University of Nebraska.

1. The current edition is, The American Law Institute, Natronar. Conference of Commissioners on Uniforar State Laws, Uniform Commercial Code (Final Text Ed. November 1951). Hereafter it will be cited only by Article or Section number.

2. Beutel, The Proposed Uniform Commercial Code as a Problem in Codification, 16 Law and Cont. Prob. 140 (1951).

3. The Code was a spare time occupation. The draftsmen and advisors had full time work elsewhere, most of them as teachers in University Law Schoo!s. Professor Llewellyn, the chief draftsman, during the time the Code was in process taught a full time schedule at Columbia and Harvard Law Schools, was on the Executive Committec as President Elect and President of the Association of American Law Schools and carried on numerous other professional activities.

4. The Commercial Codes of France and Germany which are comparable in scope but do not deal with such complicated subject matter required from seven to ten ycars time of the best legal minds in the two countries. See 21 Commencial Laws of TIIE WORLd 5, 24 id. at 6.

5. Beutel, supra note 2 , at $143-4$. 
The Code will be offered to the New York Legislature for adoption in the present session which began the first week in January, and has the support not only of the American Law Institute, the Commission of Uniform Laws and the American Bar Association, but in addition, the hearty approval of the American Banker's Association and perhaps other pressure groups. Its passage, therefore, seems certain unless organized opposition arises immediately. This is made extremely difficult because the present text was not published until last December ${ }^{\circ}$ and the commissioners' notes which are an integral part of the code ${ }^{\top}$ were not yet available at the time this article was written. It seems clear therefore, that the strategy of its supporters is to push the act for adoption in New York before the final draft can have careful study.

It is impossible in an article of this sort to begin to cover all of the details of such a tremendous work as the Uniform Commercial Code purports to be. It is possible here only to outline major characteristics and indications which point to ultimate conclusions regarding the value of the Code and the advisability of its adoption by state legislatures. But a hurried study of the present text together with a careful following of the history of the Code through its various drafts leads the writer, although he was one of the original advocates of a commercial code, ${ }^{8}$ to the reluctant conclusion that the Code should not be adopted in its present form for the following reasons:

Considering the size and importance of the project, it contains little of substantive enactment that is new, and it is not up to the quality of the laws it seels to repeal.

The language used in the new Code is strange, unduly complicated and not as uniform or as workable as that in the present Uniform Statutes covering the same subjects.

It is not a code at all but a collection of isolated and impractical statutes, which will, if enacted, cause great confusion in the commercial world.

The alleged Code does not offer sufficient predictable improvement in the substance of the laws now enacted in the current statutes to justify the tremendous task involved in the repeal and replacement of the present Uniform Laws.

Article 4 on Bank Deposits and Collections is an unfair piece of class legislation maneuvered through the American Law Institute and the Commission on Uniform Laws by pressure groups favoring the bankers over their customers. In such a form it has been, and will probably be, declared unconstitutional in many states.

6. Although the Code bears a November, 1951, date it did not reach the Institute members until after December first.

7. \$1-102.(3) (f). Commissioners' notes, called comments, on Articles 1, 2, 4, and 7 came to the writer February 2, 1952.

8. As far back as 1932 the writer recommended complete codification of the uniform commercial laws. Beutel, The NI.L. Should Not Be Amended, 80 U. of PA. L. ReT. 368, 385 (1932) ; see also Beutri's Brannan's Necotiable Instruarents Lay 1124, (5th ed., 1932); Beutel, The Proposed Bank Collection Act and Possibility of Recodification of the Law of Negotiable Instruments, 9 Tulane L. REv. 378 (1935). 
The Code as a whole is not a credit to its sponsors and if enacted will destroy uniformity and cause unnecessary confusion in the law.

It will benefit mostly the bankers and lawyers at the expense of the rest of the business community.

It should, therefore, be returned to the Institute for elimination of the current defects.

\section{The Scope OF THE CODE}

The Code by its own provisions ${ }^{\circ}$ is intended to repeal and replace seven current Uniform Laws and a number of widely adopted non-uniform statutes. The Uniform Laws to be repealed are the Negotiable Instruments Law, the Warehouse Receipts Act, the Stock Transfer Act, the Sales Act, the Bills of Lading Act, the Trusts Receipt Act, and the Conditional Sales Act. The first three of these have been adopted in every state in the union and in most of the territories. ${ }^{10}$ The Bills of Lading Act has been enacted, with variations, by the Federal government ${ }^{11}$ and by thirty-two states and territories $;^{12}$ the Sales Act in thirty-seven, ${ }^{13}$ the Trusts Receipts Act by twenty-seven ${ }^{14}$ and the Conditional Sales Act by twelve. ${ }^{15}$ But the latter has counterparts in numerous statutes adopted in those states which have not seen fit to take on the Uniform Act.

The non-uniform but widely adopted statutes which this Code will also repeal include among others, the American Banker's Association Bank Collections Code adopted in twenty or more states, ${ }^{10}$ the bulk transfer laws which appear in the statutes of almost all jurisdictions in slightly varying forms and numerous statutes having to do with the rights of creditors and the relationships of banks to their depositors.

The first question that arises is whether it is a wise policy to repeal five major and almost unanimously adopted and two minor but well established Uniform Laws and a host of lesser statutes to be replaced by this one Code. The answer, of course, must depend upon a comparison of the statutes proposed to those being replaced.

Articles 2, 3 and 7 on Sales, Commercial Paper and Documents of Title cover almost the identical material found in the Sales Act, Negotiable Instruments Law, Warehouse Receipts Act and Bills of Lading Act. These Articles cover respectively: Sales-twenty-five percent, Commercial paper-nineteen percent, and Documents of Title-eleven percent of the volume of the new Code. As

9. $\S 10-102$.

10. See 5 Unirorm Laws Anv. 6 (1950 Supp.); $3 i d$. at $6 ; 6 i d$. at 6 .

11. 39 Stat. 538 (1916); 48 U.S.C. ch. 4 , \$ 81 et seq. (1948).

12. 4 Uniform Laws Ann. 6 (1950 Supp.).

13. 1 UNIFORM LAws ANN. 6 (1950 Supp.).

14. 9A Unifora Laws ANn. 274 (1951).

15. 2 Uniform Laws ANN. 6 (1950 Supp.).

16. See Beutet's Branian on Negotiable Instruments (7th ed., 1948) 133. 
shown by the table of cross references in previous editions of the proposed Code, ${ }^{17}$ these articles comprising fifty-five percent of the whole, although in totally different language, contain approximately the same subject matter as these currently adopted Uniform Laws, and little else.

Article 8, Investment Securities, constituting eight percent of the Code and Article 9, Secured Transactions, covering sixteen percent, involve material in the Uniform Stock Transfer Act and the Uniform Conditional Sales Act with a number of major additions which will be discussed below. Thus seventy-nine percent of the new Code is a re-enactment of current uniform statutes. Article 4 on Bank Collections and Article 6 on Bulk Transfers involve almost the same theory now codified in the American Banker's Association Bank Collections Code and the various bulk transfer acts. Thus ninety percent of the Code involves re-codification of current statutes. Article 5, Documentary Letters of Credit, constituting about three percent of the whole is new. The balance of the Code is taken up with definitions and rules for interpretation. In fact over twenty percent of the entire volume is scope notes and definitions, a defect which will be discussed in detail later.

Thus it will be seen that the Code as a whole contains little subject matter that is new. One of the draftsmen has said, "Most of the Code is merely restatement."'18 There is, therefore, no urgent need for adopting it unless it is a great improvement on the current law. A detailed comparison of the statutes will show that this is not the case.

\section{The Language Used By tee Code Is Unnecessarily Technical, NEw AND ERRatic}

Numerous commentators including the present writer have pointed out again and again that, defying the practice normally found in codes of using current legal language, this Commercial Code has created an entirely new and strange vocabulary. 19 It should be noted here that the highly successful commercial codes of Europe used the ordinary legal terminology to such an extent that

17. See Uniforas Comarercial Cone XXV-XXXIV, \$41-\$52 (Proposed Final Drait Spring 1950).

18. Gilmore, The Secured Transactions Article of the Commercial Code, $16 \mathrm{LAW}$ AND Cont. PRoB. 27, 27 (1951).

19. Williston, The Law of Sales in the Proposed Commercial Code, 63 Hanv. I. Rev. 561, 569 et seq. (1950); Rabel Sales Laai in the Proposed Commercial Code, 17 U. of CHIC. L. Rev. 427,430 et seq. (1950); Rheinestein, Confliet of Lazies is: the Uniform Conmercial Code, 16 Law and Cont. Prob. 114 (1951); Kriple, The Secured Transactions Provisions of the Uniform Commercial Code, 35 VA. L. REv. 577, C01, 615 (1949); Palmer, Negotiable Instruments Under the Uniform Commercial Code, 48 Mrrer. L Rv. 255 (1950); Waite, The Proposed Newi Uniform Sales Act, 4S MIrar. L. REx. 603,604 et seq. (1950) ; Ireton, The Proposed Commercial Code, A New Deal in Chattcl Sectrity, 43 III. L. REv. 794, 818 (1949); Beutel, The Proposed Uniform Commercial Code as a Problem in Codification, 16 Law and CoNT. Prob. 141, 145 ot seq. (1951); Beutel, Comparison of the Proposed Commercial Code Art. 3 and The Negotiable Instruments Law, 30 Neb. L. Rev. 531, 533 et séq. (1951) : of. Gilmore. The Sceured Transactitn Article of the Commercial Code, $16 \mathrm{Law}$ axd Coxt. Pros. 27, 28 (1951), Everett, Securing Security, id. at 49,51 et seq. 
they have practically no definitions. ${ }^{20}$ This Code is made up of highly technical and exotic language requiring a whole set of new terms which in most cases are defined differently from the sense in which they are used in the current commercial acts familiar to the Bench, the Bar, and the commercial practice. As indicated above, over twenty percent of the volume of this Code is made up of definitions of new terms and re-defining of old ones. The Code contains over one hundred and seventy such specially defined words and of this number less than a third are used in the same meaning throughout the entire Code. The rest take on particular connotations for the special articles in which they are used.

The definitions are also cumulative; that is, defined terms are used in later definitions. So any variation of meaning is multiplied as it appears in later definitions. This sets a very intricate trap for the unwary. To illustrate the extent to which the draftsmen have employed this technique of definition upon definition, hereafter the words in quoted parts of the Code which have been defined elsewhere will be placed in italics.

The writer has set out in detail elsewhere ${ }^{21}$ over a hundred instances in which the Code uses words in an unnatural connotation. Most of these difficulties which still appear in the final draft need not be repeated here; but by way of illustration it might be noted that among many others still flourishing are: "A porson gives value" among others "by taking delivery" 22 and the identical words are also used in another place ${ }^{23}$ to define "value" itself. A "bona fide purchaser" is defined ${ }^{24}$ without the requirement of good faith, contrary to the common Anglo-American usage. ${ }^{25}$ " $P$ urchase' includes taking by sale mortgage, pledge, lien, issue or re-issue, gift [!] or any other [!] voluntary transaction creating an interest in property."26 "Bank' means any person engaged in the business of banking,"27 obviously a banker, not a bank. " 'Creditor' means an unsecured creditor and includes any representative of creditors,"28 also meaning fiduciary? Many others are discussed below.

Of the total definitions, over one hundred and thirty of the specially defined words are used in that part of the act which deals with the subject

20. In this respect contrast Louisiana's civil code, Book III, Title VII (Dainow 1947) (taken from French Civil Code) pp. 448 et seq. and German Civil Code, Seventh Section (Chang Hai Wang's Trans. 1907) pp. 95 et seq., with Article 2 of the proposed Commercial Code; Compare also German Cheque Law, 25 Commerctar Laws of ture Worts, 481 et seq., with Article 3 . It should be noted further that the Constitution of the United States, probably the most successful codification in history contains not a single definition. Cf. Franklin, The Legal Method of the Uniform Commercial Code, 16 Law and Cont. Prob. 330 (1951); Rabel, Sales Law in the Proposed Commercial Code, 17 U. of Chicago L. Rev. 427 (1950).

21. Beutel, The Proposed Uniform Commercial Code as a Problem in Codification, 16 Law and Cont. Prob. 141, 145 et seq. (1951).
22. § 7-102 (1, g, iii), § 9-108(1, c).
23. $\$ 8-303(\mathrm{c})$.
24. $\$ 8-302$.
25. See Black's Law Dictionary 143, 144 (1891).
26. $\$ 1-201(32)$.
27. $\$ 1-201(4)$.
28. §1-201(12); cf. "lien creditor" §9-301(3). 
matter of the present uniform laws to be replaced by this Code. It is significant that these uniform acts, though they were written by different draftsmen and across a period of over thirty years, in their collective similar definitions get along with less than eighty specifically defined terms, and a large proportion of most of these are used in identical meanings throughout all of the acts. Why the authors of the Commercial Code are so set to discard this long established uniformly adopted and judicially interpreted legal vocabulary for a totally new set of terms is one of the legal mysteries of the twentieth century. And their resolute refusal to reform the language after the defects have been exposed can only be explained by a stubborn and unjustifiable pride in authorship, never a characteristic of experienced draftsmen.

It was, of course, necessary in some instances for the codifiers to redefine some terms upon which judicial decisions had varied, but these were a decided minority of all the terminology and did not call for a fifty percent addition of new definitions. It suffices to say here that these new terms would greatly and unnecessarily increase the commercial, legal and judicial confusion incumbent upon the change from the established acts to the new Code if it were ever adopted.

\section{The Terainology Is Not As Unified As In Corrent Uniforar Laws}

One reading this Code gets the impression that the draftsmen met and agreed upon a few basic terms then seized their typewriters and rushed off in at least seven different directions never to return again to correlate their work.

There are certain basic terms and concepts which run throughout all commercial transactions; among these are value, good faith, the concept of holder in due course, bona fide purchaser, notice, customer, accounts, goods, issue, and many more. None of these terms are used in the same sense throughout the Code. In fact, they have a whole series of multifarious and conflicting meanings.

At the penalty of being tedious, a few examples should perhaps be set out.

$V$ alue has at least four different meanings. In Article 3 on Commercial Paper, it is a performed contract, ${ }^{20}$ a revival to the rule of Clayion's ${ }^{00}$ case

29. \$3-303: A holder takes the instrument for value

(a) to the extent that the agreed consideration has been periormed or that he acquires a security interest in or a lien on the instrusment otherwise than by legal process; or

(b) when he takes the instrument in payment of or as security for an antecedent claim against any persoss whether or not the claim is due; or

(c) when he gives a negotiable instrument for it or makes an irrevocable commitment to a third person.

[The author has supplied emphasis to cover defined terms in this and other sections of the Code infra.]

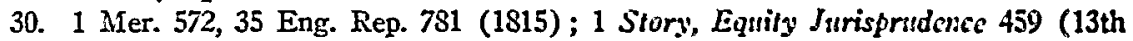
ed. 18S6); see also Beuter's Brannan, op. cit. supra note 16 at 506, et seq. 
that was decided before the area of commercial credit was understood by the courts. In Article 4 it is a concept of credit designed particularly to protect banks in all their transactions. ${ }^{31}$ In Articles 7, 8 and 9 we have the idea that giving credit is value $;^{32}$ but in Article 9 also, there is offered a concept of "new value" differing considerably from the other three types. ${ }^{33}$ Thus this Code defines three types of value and one new value. It is significant that in all the uniform laws being proposed to be repealed by this act, value has almost identical definitions. Five out of seven used "any consideration stfficient to support a simple contract,"34 and the Negotiable Instruments Law has practically the same concept with slight variations. ${ }^{35}$ Thus it appears that in

31. \$4-209: For purposes of determining its status as a holder in due course, the bank has given value to the extent that it has a security interest in an ilcm provided that the bank otherwise complies with the requirements of Section 3-302 on what constitutes a holder in due course.

\$4-208: (1) A bank has a security interest in an item and any accompanying documents or the proceeds of either

(a) in case of an item deposited in an account to the extent to which credit given for the item has been withdrawn or applied;

(b) in all other cases for which it has given credit available for withdratwal as of right, to the extent of the credit given whether or not the credit is drawn upon and whether or not there is a right of charge-back.

(2) When credit which has been given for several items received at one time or pursuant to a single agreement is withdrawn or applied in part the security interest remains upon all the items, any accompanying documents or the proceeds of either until sufficient proceeds or subsequent deposits have been received to balance withdrawals or applications.

(3) For the purpose of this section, credits first given are first withdrawn.

32. $\$ 7-102(\mathrm{~g})$ : A person gives "value" for a document of title if he takes the document

(i) in return for any consideration sufficient to support a simple contract in* cluding the extension of immediately available credit whether or not drawn upon and whether or not a charge-back is provided for in the event of difficulties in collection; or

(ii) as security for or in total or partial satisfaction of a pre-existing claim; or

(iii) by taking delivery pursuant to a pre-existing cantract for purchasc.

Cf. $\S \S 8-303$ and 9-108(1) which is identical; but see $\$ 9-108(2)$, note 33 infra.

33. $\$ 9-108(2)$. Where a secured party makes an advance, incurs an obligation or otherwise gives a new value which is to be secured in whole or in part by after-acquircd property his security interest in the after-acquired collateral shall be deemed to be taken for such new value and not as security for a pre-existing claim if the debtor acquires his rights in such collateral either in the ordinary course of his business or under contract of purchase made within a reasonable time after the making of the security agrecment and pursuant thereto.

34. UnIForm Sales ACT $\$ 76(1)$ [hereafter cited S.A.], Uniform Bul of Lading AcT $\$ 53$ [hereafter cited B.L.A.], Uniforas Stock Transfer ACT $\$ 22$ [hereafter cited S.T.A.], UNIFORM WAREHouse RECEIPTS Act \& 58 [hereafter cited W.R.A.], UNIForm TRUST RECEIPTS ACt $\$ 1$ [hereafter cited T.R.A.]. But see id., "New Value." The UNiform Condittonal Sales Act $\$ 76(1)$ [hereafter cited C.S.A.] is silent on the point.

35. Cf. Negotiable Instruments Law, $\$ \S 25,27,191$ [hereafter cited N.I.L.]. 
this respect the seven separate uniform laws have more unity than the Commercial Code.

Good faith has three different meanings where it is used, and in Article $8^{30}$ the concept is absent from certain requirements of conduct of a purchaser of paper. In Article 1, the general definition section, good faith is "honesty in fact." 37 In the Sales Article it, "in the case of a morchant includes observance of reasonable commercial standards." 38 In Commercial Paper, Article 3 is a combination of the above two. ${ }^{39}$ In Articles 4,5 and 6 , though good faith seems to be required of bankers, the good faith is of a different type from that required of other people; $; 0$ in Article $7^{41}$ it is the same as Article 3 and in Article 8, Investment Paper, the concept of "bona fide purchaser" does not seem to require good faith. ${ }^{42}$

In contrast to this, in the current uniform laws wherever it is defined including four of the acts, good faith is identically "a thing is done "in good faith'... when it is in fact done honestly whether it is done negligently or not."43 The NIL concept, more complicated than the other uniform laws, is simpler than that set out in the Code; but has been the source of much diversity of judicial opinion. ${ }^{44}$ Here again the current uniform statutes have better unity than the Code; so much more judicial difficulty can be forecast.

When these various basic elements are combined to form a concept like holder in due course, the lack of unity in the Code becomes even more striking.

The good faith purchaser for value of negotiable paper who cuts off defenses and gets better title than his vendor, appears in all sorts of guises. Although there has been some effort to unify the concept in the definition of "holder", 45 it ends there. In Article 2 he is a "good faith purchaser for value." 46 In Articles 3, 4 and 5 he is a "Iolder in due course" ; 4 in Article 7 "a holder to whom a negotiable document of title has been duly negotiatcd." 48

36. \$\&-302. Section 1-203 requiring performance of every contract in good faith has no application here. If it did, requirement of good faith in other Articles would be surplusage.

37. $\$ 1-201(19)$.

38. $\$ 2-103(b)$.

39. \$3-302(b), in good faith including observance of the reasonable commercial standards of any business in which the holdcr may be engaged.

40. $\$ 4-103(1,3$ and 4). Cf. the material discussed under Article 4 infra.

41. $\$ 7-501(4)$.

42. \$ 8-302; cf. "notice" \$ 8-304.

43. S.A. $\$ 76(2)$; B.I.A. $\$ 53(2)$; W.R.A. $\$ 58(2)$; S.T.A. $\$ 22(2)$.

44. N.I.L. § 52(3), §56; See Note, 81 U. of PA. L. REv. 617 (1933).

45. $\$ 1-201(20)$ : "Holder" means a person who is in possession of a doctuncest of title or an instrument or an investment security drawn, issued or indorsed to him or to his order or to bearer or in blank.

46. $\$ 2-403(1)$.

47. \$3-302, +104(3), 4-209, 5-103(3).

48. $\$ 7-502(1)$. 
Article 8 calls him a "bona fide purchaser," 10 and in Article 9 he has all three of the above meanings ${ }^{50}$ plus the designation "assignee who takes his assignment for value, in good faith and without notice of a claim or a defense, except as to defenses of the type which may be asserted against a holder in due course of a negotiable instrument under the Article on Commercial Paper,"51 and he also has a near kin, "Purchaser for neze value."

This single concept in the Code then has six different meanings whereas in the uniform acts such a holder is known by only three terms: "holder in due course," "53 "person to whom a negotiable [paper] has been duly negotiated," 54 and "purchaser for value in good faith without notice." has been advanced why one term like holder in due course would not be sufficient in all cases.

When one examines the ingredients which go to make up the holder in due course concept in its various forms, the confusing centrifugal force of the Code becomes even more apparent. Article 2 requires good faith so (of the first and second types indicated above) and for value (of the third type). ${ }^{57}$ Nothing is said about notice. Under Article 3, the holder in due course must be for value (of the first type) ${ }^{58}$ in good faith (of the third type $)^{59}$ and without notice. In Article 4 the same term, holder in due course, is used but the value requirement is different and holding in due course is a much narrower concept ${ }^{60}$ than under Article 3. In Article 7 the requirements are value (different from both values above), ${ }^{61}$ good faith (of the third type) and "in current course of business." ${ }^{22}$ Notice does not seem to be required at all. In Article 8 where the concept appears as "bona fide purchaser"03 value (similar to Article 7) ${ }^{64}$ without notice (entirely different from notice in Article 3$)^{65}$ is all that is required. Good faith as indicated above does not seem to be an ingredient of bona fide purchaser.

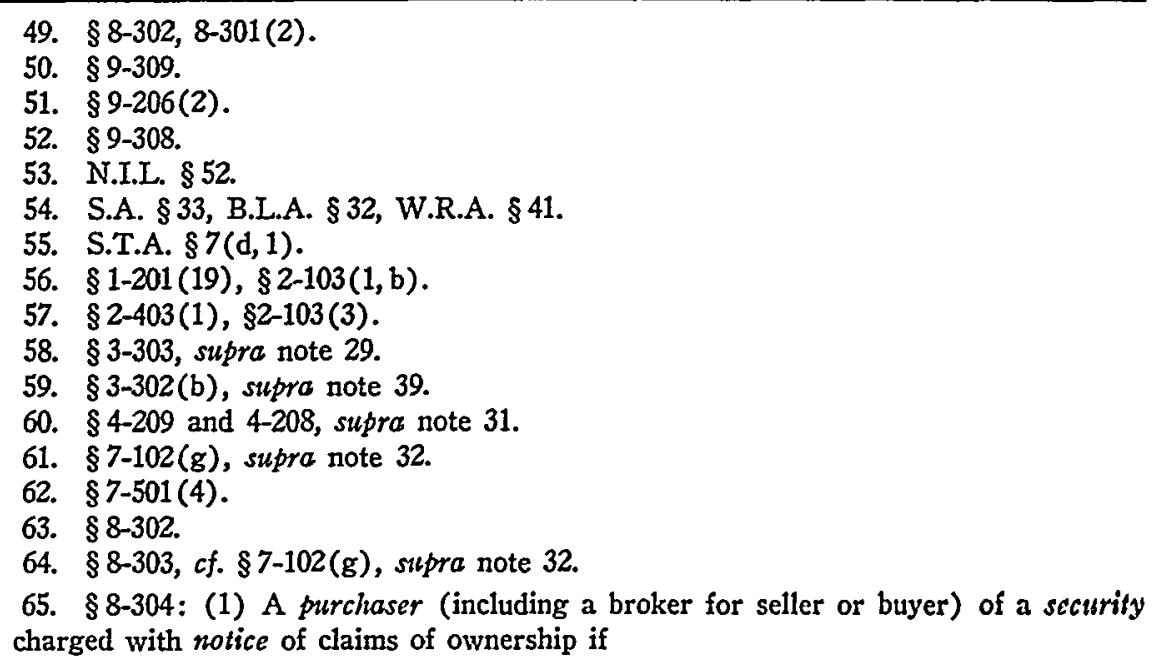
is charged with notice of claims of ownership if

(a) the security whether in bearer or registered form has been indorsed "for collection" or "for surrender" or for some other purpose not involving transfer; or 
In the current uniform acts this concept is the same throughout, requiring value, good faith, and absence of notice, ${ }^{60}$ which terms as indicated above are practically uniform. If economic research, commercial practices, or judicial decisions have in any way necessitated this complete fracturing of the concept of holding in due course, such facts are nowhere indicated in the Code and have not come to the attention of the writer. There seems to be no reason why the holding in due course concept could not be uniform for commercial paper throughout the entirety of a properly drafted commercial code. If exceptions were necessary for unique situations, they could easily be inserted.

Notice is also part of the concept of holding in due course. When one approaches this subject he comes upon one of the most fantastic combinations of double-talk and inconsistent uses of terms found any place in the eerie language of this Commercial Code. To begin with, "notice" is defined at least twice in Article 1, comes in by reference in other articles many more times, and like "value" is used in completely inconsistent fashion in the various articles where it is involved. Sections $1-201(25),(27),(26)$ contain long and complicated definitions of "notice," "notification" and "notifies", which probably include both actual notice and old fashion English common law constructive notice, ${ }^{67}$ thus opening Pandora's Box in regard to how far constructive notices affect holders of negotiable money paper. That constructive

(b) he puchases the security within six months after he has received notification that it has been lost or stolen; or

(c) the security is in bearer form and has on it an unambiguous statement that it is the property of a person other than the transferor. The mere writing of a name on a security is not such a statement.

(2) The fact that the purchaser (including a broker for seller or buyer) has notice that the registered owner holds the security for a third ferson or that the sceurity is registered in the name of a fiduciary does not create a duty of inquiry into the rightiulness of the transfer or constitute motice of claims of ownership. If, however, the proceds of the purchase are placed by the purchaser in the individual account of the fiduciary or are made payable in cash or to the fiduciary individually or the purchoser has reason to know that such proceeds are being used or that the transaction is for the individual benefit of the fiduciary, the purchaser is charged with uotice of claims of ownership. Cf. \$3-304, note 69 infra.

66. N.I.L. §52, S.A. (Substitute §38), B.L.A. \$38, W.R.A. (Substitute §47), S.T.A. $\$ \S 4,7 \mathrm{~d}(1)$ and 8.

67. \$1-201(25) (26) and (27) : A person has "notice" of a fact when

(a) he has actual knowledge of it; or

(b) he has received a sotice or stotificalion of it; or

(c) from all the facts and circumstances known to him at the time in question

he has reason to know that it exists.

(26) A person "notifies" another by taking such steps as may be reasonably required to inform the other in ordinary course whether or not such other party actually comes to know of it.

(27) A person "receives" a notice or notification when

(a) it comes to his attention; or 
notice is contemplated is shown by the fact that notice from recording acts had to be specifically excluded later. ${ }^{68}$ But this definition, although it clearly applies to all the Articles, is limited as follows: "Subject to additional definitions ... and unless the context otherwise requires." As indicated below the context otherwise requires in a number of places.

Section 3-304 which is approximately two pages long in Article 3 , is set out in the margin for handy reference." It contains "additional defini"

(b) it is duly delivered at the place or business through which the contract was made or at any other place held out by him as the place for receipt of such communications.

Notice or a notification received by an organization is effective for a particular transaction from the time when it is brought to the attention of the individual conducting that transaction, and in any event from the time when it would have been brought to his attention if the organization had exercised due diligence.

68. See §3-304(6), note 69 infra.

69. § 3-304: Notice to Purchaser.

(1) The putrchaser has notice of a claim or defense if

(a) the itstrument is so incomplete, bears such visible evidence of forgcry or alteration, or is otherwise so irregular as to call into question its validity, terms or ownership or to create an ambiguity as to the party to pay; or

(b) the prerchaser has notice that the obligation of any party is voidable in whole or in part, or that all parties have been discharged.

(2) The purchaser has notice of a claim against the instrument when he has reasonable grounds to believe

(a) that the transfer to him is a preference voidable under the law of bankruptcy or insolvency;

(b) that a fiduciary has negotiated the instrument in payment of or as security for his own debt or in any transaction for his own benefit or otherwise in breach of duty.

(3) Except as provided with respect to conditional, trust or collection itdorsements in the course of bank collections (Sections 4-203 and 4-205), the purchaser also has notice of a claim against the instrument if it has previously been indorsed conditionally or in such manner as to prohibit further negotiation and such indorsement has not beetl cancelled.

(4) The purchaser has notice that an instrument is overdue if he has rcasonable grounds to believe

(a) that any part of the principal amount is overdue or that there is an uncured default in payment of another instrument of the same series; or

(b) that acceleration of the instrument has been made; or

(c) that he is taking a demand instrument after demand has been made or more than a reasonable length of time after' its isste. A reasonable time for a check drawn and payable within the states and territories of the United States and the District of Columbia is presumed to be thirty days.

(5) Knowledge of the following facts does not of itself give the purchaser notice of a defense or claim

(a) that the instrument is antedated or postdated;

(b) that it was issued or negotiated in return for an executory promise or accompanied by a separate agreement, unless the purchaser has notice that a defense or claim has arisen from the terms thereof;

(c) that any party has signed for accommodation; 
tions" of notice; and throughout the Article the context "otherwise requires."70

Under Section 3-304 a purchaser who has notice of a "claim or defense" apparently cannot be a holder in due course. Although claims and defenses are key technical words, they are nowhere defined and are certainly not used in their ordinary meanings. Under Section 3-304(1) a purchaser has notice of such "claim or defense" when the instrument contains infirmities of various types as the term is used in the NIL. ${ }^{71}$ For example, if a drawer draws a check intended to be payable to bearer and leaves the name of the payee blank, but has no other defense, it is clear that no claim or defense in the ordinary sense exists. Yet the purchaser who takes this instrument has "notice of a claim or defense." On the other hand, if a maker writes a check, puts in the figures $\$ 100$ then crosses them out, puts in $\$ 150$ and issues the check in that form, it is clear that there is no claim or defense, only an infirmity; but under the NIL one cannot be a holder in due course because the instrument is not regular on its face. However, under this Article, the holder "has notice of a claim or defense" where none exists and is also not a holder in due course. Conversely, under subsection (1) (b) a holder does not have notice of discharge unless he has notice that "all parties have been discharged." Thus, if a co-maker or surety or indorser has been discharged and the holder knows it at the time he takes the instrument, it is clear that there are defenses to the instrument and that these defenses are known to the taker. But under the clear provisions of subsection (1) (b), he does not have notice of a "defense" and may be a holder in due course. This is not a mere oversight but is definitely contemplated by other provisions throughout the act making him subject to the defense even though a holder in due course. ${ }^{20} \mathrm{On}$ the other hand, as to claims against the instrument, it is clear that subsection (2) contemplates constructive notice of fiduciary claims, thus dragging in all the exceptions and many more which the Uniform Fiduciary Act created to Section 56 of the NIL. But by express provisions of subsection (5) and of the previous commissioners notes to other sections, ${ }^{73}$ if an instrument be

(d) that an incomplete instrument has been completed, unless the purchaser has notice of any improper completion;

(e) that any person negotiating the instrument is or was a fiduciary;

(f) that there has been default in payment of interest on the instrument or in payment of any other instrument, except one of the same series.

(6) The filing or recording of a document does not of itself constitute solice within the provisions of this Article to a person who would otherwise be a holder in duc course.

(7) To be effective notice must be received at such time and in such manner as to give a reasonable opportunity to act on it.

70. Cf. $\$ \$ 3-305$ (2) (e), 3-415 (4), 3-417 (1) (b) , 3-602, 3-603, 3-605 (3). It is not clear whether $\$ \$ 3-501$ to $3-511$ on presentment, notice and dishonor affect notice as here discussed, but they may.

71. See Beutel's BranNan op. cit. supra note 16 , at 706.

72. See $\$ 3-305(2)(\mathrm{e}), \S 3-602$.

73. Proposed Final Draft \$\$-3-205, 3-206 (Spring 1950). 
indorsed "Pay John Doe in trust for Richard Roe," it is perfectly clear that it creates on its face notice of Richard Roe's claim on the instrument, but under the specific provisions of subsection (5) (e) this fact does not give the purchasers "notice of the claim." Even though he has read the indorsement, the holder can still be a holder in due course and take free of the claim of Richard Roe even when he knows about it, that is, unless he is charged with constructive notice under subsection (2) that the fiduciary is operating in breach of trust. However, by specific provision of subsection (3), except as provided in the Bank Collection Article 4, a person who takes an instrument conditionally indorsed has "notice of a claim" from the indorsement even though he gets no such notice from the indorsement in trust. ${ }^{74}$ Just why there should be a distinction between these different indorsements and how one can tell from the words of the indorsement when it falls out of one class and into another, so far as notice is concerned, is quite beyond comprehension of the ordinary lawyer and is likely to create endless litigation.

So claims may not be "claims," defenses may not be "defenses" and a taker may have a "notice of claim or defense" where no claim or defense exists. All of which leads one to wonder what would happen if a man purchased an instrument under facts which caused him to have "reasonable grounds to believe"75 that this vendor was negotiating in breach of trust, but, when as a matter of fact, the maker had a defense of fraud which had nothing to do with the trust. Does or does not the taker have "notice of a claim or defense?"

The Negotiable Instruments Law is clear on these questions. He must have actual notice of infirmities, maturity or defects of title ${ }^{76}$ or must have taken in subjective or objective bad faith ${ }^{77}$ to deprive him of the rights of a holder in due course. Just what is the pattern of state of mind and surrounding facts under Article 3 is anybody's guess.

In Article 4, banks apparently are not charged with notice outside of their instructions. ${ }^{78}$ Likewise, in Article 7 notice of claims apparently does not cut off due negotiation unless bad faith can be proved. ${ }^{70}$ Article 8, like Article 3, has another long and complicated section ${ }^{80}$ on the subject of notice but in different words from those found in Article 3, but which will eventually lead to the same type of difficulty in application of the concept to a series of commercial facts. ${ }^{81}$

\footnotetext{
74. $\$ 3-206(\mathrm{c})$.

75. $\$ 3-304(2)(b)$, supra note 69.

76. N.I.L. $\$ 55$.

77. N.I.L. $\$ 52,56$.

78. $\S 4-203, \S 4-205(2)$.

79. $\$ 7-501(4)$.

80. § 8-304 supra note $65 ;$ cf. \$\$ 8-202, 8-305.

81. It should be noted that notice as discussed here is used only as an ingredient of holding in due course, and does not involve other types of notice to creditors, to indorsers and to others in matters of that sort; where, again, separate provisions and processes are created for each Article, to cover each particular situation. For example see note 70 sipra.
} 
It should be noted again that in the current Uniform Acts notice is defined only once in the Negotiable Instruments Law. Throughout the other sections the concept is uniformly left to the courts.

This conflict in the meaning of terms is not limited to the concept of holding in due course and its ingredients, but applies to commercial terms used all through the code.

Warranty. A second example of a failure to use general terminology is found in the manner in which the Code deals with the concept of warranty. Although this subject is currently covered by at least five uniform laws 82 and the Contracts Restatement. ${ }^{83}$ all agree that a transferor of commercial paper whether negotiable or not is subject to at least four basic warranties: (1) the paper is genuine: (2) the transferor has title or right to transfer; (3) he has no knowledge of disabling facts; and (4) the obligation is valid.8s As is to be expected there is a variation of wording in the statutes but in many the terminology is almost identical. Unity here would therefore seem to be indicated, and appears to be possible to accomplish, with variations necessary only to cover special instances. But what has the Code done? Axticles 3 and 4 though couched in almost entirely different language set out seven or eight warranties; ${ }^{85}$ Article 7 covers three, ${ }^{80}$ and Article 8 substantially the same three but in quite different verbiage ${ }^{8 T}$ and with some additions as to agents, brokers', registrars', trustees' and transfer agents' warranties..$^{88}$ Now due to different verbiage, it is doubtful if the warranties set out are coexistent even when the different types of paper appear in the same transaction; but what is worse, the remaining five articles (except Sales, Article 2) though they all cover situations where transfers of commercial paper and contracts are involved, seem to be silent on this basic subject. ${ }^{89}$ The Sales Article sections on warranties ${ }^{90}$ are couched in language which seems to have no relation to the subject elsewhere in the Code.

Customer has at least two different meanings. In Articles 3 and 4 it is a person having a bank account; in Article 5 a buyer of credit; in none of these articles is the term used in its most common commercial meaning. $\$ 11$.

82. N.I.L. $\S \S 65,66$; S.A. $\$ \S 13-16,36$; B.L.A. $\S \S 35,36$; W.R.A. $\$ \S 44,45$; S.T.A.

\&3. $\$ 175$.

84. See Beutel, Materiats and Cases on Uniforar Comarerctal Laws 410 (1950).

85. $\$ \$ 3-417,4-207$.

86. $\$ 7-507$.

87. $\$ 8-305(1)$.

88. $\$ \$ \&-305(2), \&-20 \&$.

89. But see $\$ 9-206(3)$.

90. $\$ \$ 2-312$ to $2-318$.

91. $\$ \$ 3-102(3) ; 4-104(1)(e)$ : "Customer" means any person having an accouss with a bank or for whom a bank has agreed to collect itcons and includes a bank carrying an accossnt with another bank.

$\S 5-103(1)(\mathrm{g}):$ A "customer" is a buyer or other ferson who causes a bon?: to issue a credit. 
Account has at least ${ }^{92}$ three defined meanings. In Articles 3 and 4 it means bank account $;^{93}$ in Article 9 it has contradictory definitions. In 9-105(a),

"Account Debtor means the person who is indebted on account, chattal paper or contract right;"

while in $9-106$ it means

"a right to payment for goods sold or leased or for services rendered

which is not evidenced by chattel paper."04

"Goods" also has three definitions ${ }^{95}$ and is further complicated in Article 2 by "Future goods," "Lot" and "Commercial Unit" the terms "Consumer's Goods," "Equipment," "Farm Products" and "Inventory" which terms all seem to be included in the definition of goods but are not mutually exclusive. ${ }^{07}$

Even casual readings of the Code will disclose many more cases where words are used in multiple meanings. ${ }^{98}$

\section{It Is Not A Code But An Unworkable Collection of Statutes}

One of the chief characteristics of a good code is that it states in simplified outline the basic law governing the transactions which it seeks to regtlate. From what has already been said it is clear that this Uniform Commercial Code is not a code at all but a collection of highly technical, uncorrelated statutes attempting to regulate in detail a series of unrelated and minute commercial transactions. The definitions of terms used indicate that in almost every section the draftsmen have attempted to provide for particular situations or to codify known judicial decisions.

If the needs of the regulation of commerce required it, lawyers, courts and business men could probably learn this new vocabulary. It would perhaps take a period of twenty-five or fifty years of confusion due to delving into the implications of each term before they became clear to the "trade." Theoretically each type of paper and each class of transactions might eventually develop its own particular intricate rules which differed from every other. But practically, this type of law is not workable in modern business because various types of commercial paper and goods are transferred simultaneously

92. For use in another sense see §3-206.

93. $\S \S 3-102(3)$; 4-104(1) (a): "Account" means any accostht with a bank and includes a checking, time, interest or savings account.

94. Of course it is intellectually possible to distinguish between account as used in "Account Debtor" and in "Account"; but what is the practical value of this type of intellectual gymnastics when there are plenty of other words available to express the ideas?

95. $\S \S 2-105$, two; 9-105(f); See $\S 2-107$.

96. §2-105.

97. \$9-109.

98. A few of these are: "Money" $\$ \$ 1-201(24), 3-107$; "Issuer" $\$ \S 3-102(1)$ (a), 5-103 (c), 7-102(1) (f), 8-201; "Buyer in ordinary course of business" \$\$ 1-201 (9), 2-402, 3-302(b), 9-307; See §7-501(4). 
and in the same transactions. Single sales often involve the exchange of goods, documents of title and negotiable money paper. Security transactions more often than not require the simultaneous transfer of stocks, bonds, commercial paper, and documents of title. As this "Code" is now drawn, from two to six conflicting rules of law may apply to the rights of the parties to the same transaction. Each type of paper and goods has its own legal vocabulary and set of rules governing its particular transfer. Thus a confusion is assured and uniform application of the law becomes an impossibility.

One of the commonest transactions in banking is the transfer of drafts with documents of title attached. Under the proposed "Code", if both types of paper were stolen, a bank taking a transfer of such paper for credit would be both a holder in due course of the draft ${ }^{93}$ and "a holder to whom the document of title has been duly negotiated," ${ }^{109}$ of the document of title; but a merchant taking the same paper for credit is a holder to whom the "docisment has been duly negotiated" of the document of title ${ }^{101}$ but not a holder in due course of the draft. ${ }^{102}$ Translating the language, the bank has both instruments free of the defenses and claims of the former owner. The merchant has such rights in the document of title, but must return the draft to its true owner even though the transaction contemplates that the document of title shall be held as security for the draft. Further, if the merchant took the paper in chain of title after the bank, then he may possibly hold both instruments free from the rights of the former owner. ${ }^{103}$ But if he preceded the bank he would be in the predicament indicated.

Under the present uniform laws all the cases above would be treated alike. Both the bank and the merchant would, under the words of the statutes, be holders for value and would take it free from defenses or claims of former owners. ${ }^{104}$

Due to the lack of unity in the "Code," difficulties of this sort are inherent in every transaction where two or more types of goods or paper are transferred as part of the same business deal. In addition to the fact that every type of paper has its own intricate set of rules of law, it must be born in mind that bankers, ${ }^{105}$ brokers, ${ }^{106}$ merchants ${ }^{107}$ and just ordinary people have

99. $\$ \S 4-209,4-208$, supra note 31 .

100. $\$ \$ 7-502,7-501$.

101. $\$ \S 7-501,7-102(\mathrm{~g})$, supra note 32 .

102. \$3-303 supra note 29 .

103. $\$ \$ 4-209,3-306,3-201$. The banls is a holder in due course only to the estent of its lien, $\$ 4-208$; and $\$ 3-201$ (1) gives the transferee only the rights of the transferor. The courts would probably apply the principal of Burnes v. New Mineral Fertilizer Company, 218 Mass. 300, 105 N.E. 1074 (1914), that to protect the bank's security interest, the purchaser, not a holder in due course, could collect the face of the note.

104. N.I.L. $\$ \$ 25,56$; see conflicting cases. BEutez's BRAwran, sttpra note 16, $\$ 499$;

S.A. $\$ 76$ (substitute $\$ 38$ ); B.I.A. $\$ \$ 53,38$; W.R.A. $\$ 58$ (substitute $\$ 47$ ).

105. Among others see $\$ \$ 4-102,4-103(3), 4-209,4-208$.

106. Among others see $\$ \$ \&-313, \$-318, \$-306(2), 2-104(1), 2-707$.

107. Among others see $\$ \$ 2-103(1)(b), 2-104(3), 2-201(2), 2-205,2-209(2), 2-603$. 
separate rules governing their business conduct even though they are engaged in the same transactions.

Just what the business world can make out of this maze of "gobbledygook" remains to be seen. If so comparatively simple a statute as the Negotiable Instruments Law caused numerous conflicting court decisions it is certain that this "Code" will cause monumental conflict which would be much more widely dispersed than any now surrounding the present uniform statutes.

\section{The Rules of Interpretation and Application Are Impractical}

Seeds of even greater confusion are embodied in those provisions of the "Code" indicating what law applies to a particular transaction. Section 1105 , which purports to codify the rules of conflict of laws governing the application of the "Code", sets up four separate rules to be applied by the courts depending upon which of the articles is involved. Sales, Article 2; Documentary Letters of Credit, Article 5; and Documents of Title, Article 7 , have one set of rules. Commerical Paper, Article 3; and Bank Deposits and Collections, Article 4, have another. Investment Securities, Article 8, still a third. Bulk Transfers, Article 6; and Secured Transactions, Article 9; a fourth. These four rules of law, set out in the margin, ${ }^{108}$ are in substance somewhat alike. Roughly, they provide that whenever a transaction whose subject matter is covered by this "Code" in any way touches the forum, this

108. § 1-105: Applicability of the Act; Parties Right to Choose Applicable Law.

(1) Article 1 applies to any contract or transaction to which any other Article of this Act applies.

(2) The Articles on Sales (Article 2), Documentary Letters of Credit (Article 5) and Documents of Title (Article 7) apply whenever any contract or transaction within the terms of any one of the Articles is made or occurrs after the effective date of this Act and the contract or

(a) is made, offered or accepted or the transaction occurs within this state;

(b) is to be performed or completed wholly or in part within this state; or

(c) relates to or involves goods which are to be or are in fact delivercd, shipped or received within this state; or

(d) involves a bill of lading, warehouse receipt or other document of tille which is to be or is in fact issued, delivered, sent or received within this state; or

(e) is an application or agreement for a credit made, sent or received within this state, or involves a credit issued in this state or under which drafts are to be presented in this state or confirmation or advice of which is sent or reccived within this state, or involves any negotiation within this state of a draft drawn under a credit.

(3) The Articles on Commercial Paper (Article 3) and Bank Deposits and Collections (Article 4) apply whenever any contract or transaction within the terms of either of the Articles is made or occurs after the effective date of this Act and the contract

(a) is made, offered or accepted or the transaction occurs within this state; or

(b) is to be performed or completed wholly or in part within this statc; or 
"Code" shall apply. Not only is it in "disregard of any known system of conflict of laws;"109 and denounced by all authorities writing on the subject;10 but if ever enacted it would be the destruction of uniformity; and would continually raise the spectre of choice of forum which is the bane of the existence of practicing lawyers and businessmen alike.

The draftsmen glibly justify this exception by a naive argument about as follows: "It is a good code so let's apply it in all possible cases." Although one might doubt the major premise, the practical results of adopting such an argument would be disastrous. Take for example a hypothetical case. A merchant in Boston buys goods in San Francisco giving a negotiable note payable in thirty days. The San Francisco vendor discounts the note at his bank, with chattel paper or collateral attached. The goods are shipped across country passing through about fifteen states. The "Code" is not in effect in either Massachusetts or California, but, in the process of collection the note is indorsed in New York where the "Code" has been enacted. The parties to the transaction under Section 1-105 may find themselves bound by rules of law in any one of the fifteen states where the "Code" may be enacted and where either party might choose to sue.

The whole Section 1-105 is obviously a club to force adoption of the "Code" in all states, but if it were so adopted that would not end the difficulty. The history of well-drafted uniform laws such as the Sales Act and Negotiable Instruments Law has shown that interpretation of the best lang-

(c) involves commercial paper which is made, drawn or transferred within this state.

(4) The Article on Investment Securities (Article 8) applies whenever any contract or transaction within its terms is made or occurs after the effective date of this Act and the contract

(a) is made, offered or accepted or occurs within this state; or

(b) is to be performed or completed wholly or in part within this state; or

(c) involves an investment security issued or transferred within this state. But the validity of a corporate security shall be governed by the law of the jurisdiction of incorporation.

(5) The Articles on Bulk Transfers (Article 6) and Secured Transactions (Article 9) apply whenever any contract or transaction within their terms is made or occurs after the effective date of this Act and falls within the provisions of Section 6-102 or Sections 9-102 and 9-103.

(6) Whenever a contract, instrument, document, securily or transaction bears a reasonable relationship to one or more states or nations in addition to this state the parties may agree that the law of any such other state or nation shall govern their rights and duties. In the absence of an agreement which meets the requirements of this subsection, this Act governs.

109. Rabel, The Sales Law in the Proposed Commercial Code, 17 U. of Crr. L. REv. 427, 428 (1950).

110. See Rheinstein, Conflict of Laws in the Uniforn Commerial Codc, $16 \mathrm{Law}$ And Cont. Prob. 114, 115 (1951) and numerous authorities there cited; Rheinstein, Bool: Review, 26 Ind. L. J. 576, 581 (1951) ; Beutel, The Proposed Uniform Comsncrial Code, 16 id. 141,160 et seq. 
uage (to say nothing of the extra difficulties made certain by the exotic phraseology in this "Code") is bound to reach conflicting results in various states. ${ }^{111}$ With a provision such as Section 1-105, then, legal advice will be impossible because it will have to take into consideration court decisions interpreting the "Code" where it could not even have been foreseen that the law would apply, simply because of a fortuitous routing of shipment, collection, and like transactions beyond the control of the principal parties to the original contract. When it is understood that practically all of the transactions which this "Code" will cover involve interstate commerce, and that it may never be uniformly adopted in all states, the potentialities of mischief for this section are legion. The practical effect would be that each statutory or judicial departure from the uniform rule in any state would be potentially multiplied by the number of other states touching its transactions. This would be the death of uniformity. There would be the further difficulty that in international trade, the courts would be instructed to apply the law of the American forum to the details of the commerce of the world. 'This would not increase our popularity abroad.

But the difficulty does not end there. Article 4 on Bank Collections provides that "the liability of the bank for action taken by it in the course of collections is governed by the law of the place where the bank is located." 11 " So a different rule of law applies especially for the benefit of banks. In the case of secured transactions, Article 9, the law of the principal office of the debtor or the assignor of the accounts governs. ${ }^{113}$ Now applying these exceptions to the illustrations above, the law of Massachusetts, the location of the office of debtor, applies to him. The law of California to the discounting bank and the law of the state of its own locality to each bank in the process of collecting the paper; then the law of any of the other dozen or more states which by chance the goods or paper happen to touch, may govern the rest of the parties to the deal depending upon where the "Code" is enacted. Just how any court, even with the wisdom of a Solomon, can administer such a law is not clear.

When it is remembered that the complete adoption of the statutes which this "Code" purports to replace has taken over fifty years and is not yet consummated, at least a half a century of confusion seems to be assured by these provisions alone. ${ }^{114}$

Some measure of relief is accorded by Section 1-105(6) which allows the parties to stipulate the governing law in advance, but woe to the unsophisticated who do not know or use this provision.

111. The effect of this history is discussed at length in BEUTEx's BRANNAN, supro note $16, \mathrm{c} . \mathrm{V}$.

112. $\S 4-102(2)$.

113. $\$ 9-103$.

114. See Braucher, Federal Enactment of the Uniform Commercial Code, 16 Law ANd Cont. Prob. 100, 104 (1951). 


\section{There Is Not Sufficient Imiprovenent In Substantive Provisions To Justify Replacenrent of the Present Uniform Statutes}

There would be no object in risking all of the confusion and difficulties mentioned above unless this "Code" were an outstanding improvement upon the statutes which it seeks to replace. Unfortunately, this is not the case.

Articles 2, 3 and 7; Sales, Commercial Paper, and Documents of Title, making up fifty-five percent of the "Code" do little more than duplicate existing uniform statutes already adopted in an overwhelming majority of the jurisdictions. The Uniform Laws on Sales, Warehouse Receipts and Bills of Lading covering Articles 2 and 7 of the "Code," incidentally, its best parts, have been extremely successful in their administration by the courts. This is partly due to their excellent draftsmanship and partly to the fact that the treatise on sales by their principal draftsman, Professor WVilliston, 115 has made it possible for the courts to work out the intention of the act in most cases. Professor Llewellyn, the chief draftsman of the "Code" has long believed that he could create a better statute; but the preceding material indicates that he has failed to do so, and most of the comments written to date on these parts of the "Code" seem to concur."

In the field covered by the Negotiable Instruments Law, because it was the first and most widely adopted of the statutes and because it was accompanied by no commissioners' notes or authoritative treatise, there have been numerous conflicting decisions and numerous amendments. But of late, much of this confusion in the decisions has tended to disappear through re-publication of the commissioners' notes and the consequent better understanding of the Negotiable Instruments Law itself. ${ }^{117}$ As indicated elsewhere and in much more detail, Article 3 on Commercial Paper fails miserably both in scope and in vocabulary to be as good as the present Negotiable Instruments Law. ${ }^{118}$ In its scope it goes back to the British Bills of Exchange Act covering only checks, drafts, promissory notes and certificates of deposit. But it goes even further back to English commercial law to revive many of the concepts found there which had been completely abandoned in modern practice. As indicated above, its language is as novel and difficult as any in the "Code",

115. Writiston on Sales (1909) (2d ed. 1924) (Rev. ed. 1948). All this learning is set aside by the "Code."

116. Williston, The Law of Sales in the Uniform Conmercial Code, 63 HARv. L. REv. 561 (1950); Waite, The Proposed Uniform Sales Act, 48 Mrcr. L. Rev. 603 (1950); See Rabel, The Sales Law in the Proposed Comnucrial Code, 17 U. of CHI. L. Rev. 427 (1950) ; Latty, Sales and Title in the Proposed Code, 16 LAw Axd Co:ir. Prob. 3 (1951); Comment, Remedies for Total Breach of Contract Unter the Uniform Reviscd Sales Act, 57 Yale L. J. 1360 (1948) ; but see Corbin, The Un:iform Comnercial Code Should It Be Enacted, 59 Yale L. J. 821 (1950).

117. See Brannan on Negotiable Instrudrents iii (Beutel's 6th ed. 1938).

118. Beutel, Comparison of the Proposed Conmercial Code Article 3, and The Negotiable Instruments Law, 30 NEB. L. REv. 531 (1951). 
and commentators on earlier drafts almost uniformly agree that it has failed to accomplish its purpose of substantial improvement on the Negotiable Instruments Law. ${ }^{118}$

As a matter of substantive law, therefore, there would be no net gain and probably considerable loss by adopting the fifty-five percent of the "Code" which would repeal these four earlier statutes.

Articles 8 and 9, Investment Securities and Secured Transactions, replace the Uniform Stock Transfer Act and the Uniform Conditional Sales Act, and parts of the Negotiable Instruments Law, making considerable addition thereto. Article 8, only eight percent of the "Code," covers the negotiability of corporate stocks and bonds and would be an improvement if it were not for errors in draftsmanship such as its treatment of bona fide purchaser discussed above and others such as the provision in Section 8-301(2) that a "bona fide purchaser acquires perfect title to the security" rather than holding "the instrument free from any defect of title from prior parties, and free from defenses available to prior parties." ${ }^{120}$ As this provision is now worded, fiduciaries, agents, trustees and other persons acting in a representative capacity take the paper free and clear of claims of their principals. ${ }^{121}$ Errors of this type, which are numerous, ${ }^{122}$ make adoption in the present form highly inadvisable. If Article 8 were worded to correspond to current legal vocabulary it might well be adopted as a separate uniform statute, but actually there is no need to adopt the whole "Code" in its present form just to get codification on the subject of corporate securities.

In theory, Article 9 on Secured Transactions is a laudable attempt to replace the Uniform Conditional Sales Act with one enactment covering all security transactions providing for means of perfecting the security, transfer of the principal paper for which security is given and of securities themselves; also for recording for the protection of the security holder and third parties. There is no doubt that a uniform code providing a workable basis for accomplishing these ends would be a great step forward but it is cloubtful whether Article 9 has accomplished these ends. It is the boast of the draftsmen that

"Article 9 deliberately cuts loose from all anchorage in the past. It cuts across what have been regarded as separate fields of law, introduces a

119. Palmer, Negotioble Instruments Under the Uniform Commercial Code, 48 Mich. L. Rev. 255 (1950); Kripke, Chattel Paper as a Negotiable Sectrity Under the Uniform Commercial Code, 59 YALE L. J. 1209 (1950); Comment, The Fictitious Payce and the U.C.C.-The Demise of a Ghost, 18 U. of CHI. L. Rev. 281 (1951); but see Cosway, Innovations in Articles Three and Four of the Uniform Commercial Code, 16 LAW AND CONT Prob. 284 (1951).

120. N.I.L. $\$ 57$.

121. This defect is discussed at length in Beutel, The Proposed Uniform Commercial Code, 16 LAW \& Contenar. Prob. 141, 149 ff. (1951).

122. $\$ \$ 7-502$ (1) (a) (b) ; 3-305, 8-301(2), 8-304 supra note 65. 
completely new terminology, incidentally repeals much old law, and in the process creates, and attempts to solve, new problems of its own."123

But no economic data is offered to show that such a sweeping change in the law is necessary, and there seems to be little, if any, supporting research to indicate that of all the possible changes, this is the one most likely to succeed in better regulating the security field.

It seems to be a rash shot in the dark with plenty of defects. In the first place, it is so complicated in its concepts of the law involved and so intricate in its draftsmanship as to defy description in an article of this scope. An entire treatise would be required to untangle and describe the legal concepts created in this Article. Already there has been as much written about it as the whole of the rest of the "Code."12s A few examples will tend to illustrate the problems of interpretation involved.

Section 9-302, dealing with the question of when filing is required to protect a security agreement provides that in the case of consumers goods and farm equipment "not in excess of $\$ 2500.00$ " no filing is necessary to perfect a security interest for purchase money, i.e., a conditional sale and the like. But under the provisions of Section 9-307(2) such an interest must be filed to protect against a bona fide purchaser of such goods for his own use. It is hard to see what difference recording would make to such a purchaser but, nevertheless, it is one of the numerous exceptions within exceptions found all through this article.

Section 9-206 makes the transferability of negotiable paper secured by security agreements depend on whether the goods dealt in are consumers goods or otherwise. And a definition of consumers goods ${ }^{125}$ does not make it clear

123. Gilmore, The Secured Transactions Article of the Commerial Code, 16 LAw \& Conterrp. Prob. 27, 28 (1951). "See Comment No. 3 to \$9-105 (Spring Draft 1950) referring to the terms 'debtor' and 'secured lender' used in Article 9: 'It is necessary to have a set of terms to describe the parties to a security transaction, but the selection of the set of terms applicable to any one of the existing forms (for eximple, mortgagor and mortgagee) might carry to some extent the implication that the existing lav referable to that form was to be used for the construction and interpretation of this Article. Since it is desired to avoid any such implication, a set of terms having no common-lav or statutory roots has been chosen." "

124. Article 9 has been discussed, among others, in the following articles: Dunham, Inventory and Accounts Receizable Financing, $62 \mathrm{HARv}$. L REv. $58 \mathrm{~S}$ (1949); Llewellyn, Problems of Codifying Security Law, 13 Law \& ConTEarp. Pros. 687 (1948); Ircton, The Proposed Commercial Code: A New Deal is Chattel Security, 43 In. I. Rev. 794 (1949); Kripke, The "Secured Transactions" Prozisions of the Untiform Commercial Code, 35 VA. L. Rev. 577 (1949) ; Kripke, Chattel Paper as a Negotiable Specislty sssder the Uniform Cosmercial Code, 59 YALE L. J. 1209 (1950); Gilmore, The Scetred Transactions Article of the Commercial Code, Everett, Securing Security, Countryman, The Sectred Transactions Article of the Commercial Code and Scction 61 of lise Bant:ruptcy Act, all in 16 Law \& Contearf. Prob. 27, 49 and 76 (1951). All of 13 Law \& CONTENIP. ProB. 553-702 (1948) was devoted to the problem.

125. §9-109(1): Goods are

(1) "consumer goods" if they are used or bought for use primarily for personal, family or household purposes. 
whether an inventory of the same articles in a merchant's shop falls within the technical definition of consumers goods or not. ${ }^{120} \mathrm{But}$, at any rate, whether or not the holder of negotiable paper secured by such agreements for the sale of consumers goods can enforce his rights against the purchaser is made to depend upon the form of which he brings his suit against the purchaser. ${ }^{127}$ If he sues to enforce the security agreement, in such case he is not a holder in due course. On the other hand, if he sues on the Negotiable paper itself instead of enforcing the security agreement he apparently has the rights of a holder in due course. ${ }^{128}$ Sub-section (2) ${ }^{120}$ of this same Section also creates a new type of negotiation based upon a fictitious agreement not to assert claims or defenses against the holder in due course of negotiable paper and the security agreement. This apparently gives security agreements transferred with negotiated paper only such transferability as can be achieved by contracts for the benefit of a third party and estoppel. Transferees of finders, thieves, converters and similar wrong doers who break the chain of assignment apparently have no rights in the security unless we also fictitiously assume that the holder in due course of negotiable paper so secured has fictitiously read, understood and relied upon the fictitious agreement which is presumed to have been made by the purchaser. ${ }^{130}$ When one considers that these resutts could have all been accomplished by the simple words that "security agreements attached to negotiable instruments are as negotiable as the instrument itself," 131 one sees that so far as draftsmanship is concerned, this is truly the mad genius article of the "Code."

One further example will suffice. In attempting to cover all possible situations this Article has been drafted in long and complicated sections contain-

126. $\$ 9-109(4)$ : "inventory" if they are held or are being prepared for salc or ure to be furnished under a contract of service or if they are raw materials, work in process or materials used or consumed in a business. If goods are inventory they are neither farm products nor equipment.

127. \$9-206(1): An agreement by a buyer of consimer goods as part of the comtract for sale that he will not assert against an assignee any claim or defense arising out of the sale is not enforceable by any person. If such a buyer as part of one transaction signs both a negotiable instrument and a security agreement even a holder in duc course of the negotiable instrument is subject to such claims or defenses if he seeks to enforce the security interest either by proceeding under the security agrecment or by attaching or levying upon the goods in an action upon the instrument.

128. $\S \S 3-112,3-119,9-309$.

129. $\$ 9-206(2):$ In all other cases an agreement by a buyer that he will not assert against an assignee any claim or defense arising out of the sale is enforccable by an assignee who takes his assignment for value, in good faith and without notice of a claim or defense, except as to defenses of a type which may be asserted against a holder in duc course of a negotiable instrument under the Article on Commercial Paper [Article 3]. A buyer who as part of one transaction signs both a negotiable instrument and a sccurity agreement makes such an agreement.

130. See, Beutel, Negotiability by Contract, 28 ILL. L. REv. 205, 219 (1933).

131. See suggestion of Kripke, Chattel Paper as a Negotiable Security, 59 YALE L. J. 1209, 1227 (1950). 
ing exceptions within exceptions and exceptions on exceptions. Section 9-312, extending over two pages, starts off: "When conflicting security interests are attached to the same collateral, such interests rank in the order of time of perfection with the following exceptions:" and then follow eight sul-sections of exceptions covering two full pages. Sub-sections (1), (3), (4) and (5) contain successive exceptions to each other and sub-section (8) refers to three other sections, ${ }^{132}$ themselves over two pages long, which are exceptions to this section and in turn contain numerous sub-exceptions of their own. Here the genius of draftsmanship reaches its full fruition.

It need scarcely be said that the Uniform Conditional Sales Act which this article intends to replace and enlarge, now covers bailment leases and conditional sales in fairly clear and simple language. The advantages of broader coverages if any, set out in Article 9 are more than offset by the complicated draftsmanship and the administrative set up which provides three or four places for filing various types of security agreements. ${ }^{133}$ In fact, the procedure is so complicated that no secured creditor can safely protect his interests without expert legal advice, if at all.

This portion of the discussion so far has accounted for eighty-five percent of the subject matter of the "Code" and there seems to be no valid reason why the present uniform laws should be replaced by these articles of the "Code." On the contrary, the present uniform laws are far more useful than the new provisions would be if enacted.

The remaining fifteen percent of the "Code" which is new covers bulk transfers, letters of credit and bank collections. The first, Article 6, Bull: Transfers, is not particularly significant because the business involved in this area of sales is mostly local and seldom involves conflict of laws. MIost states have fairly acceptable statutes on this subject and there is little necessity therefore for the adoption of uniform statutes in this field.

The Documentary Letters of Credit Article constituting only three percent of the "Code" is new. If, on further study, it proves useful, it could be detached and enacted as a uniform statute with less confusion than to leave it in the present code.

\section{Article 4 -Bank Deposits and Collections, is A Prece of Vicious Class Legislation}

There remains therefore only the discussion of Article 4 on Bank Collections. This constitutes eight percent of the entire "Code" and needs careful scrutiny both as to its history and its substantive provisions. For a long time the statutes and decisions on bank collections have been in a very bad state. In the face of conflicting decisions and statutes on almost every aspect of the subject, bankers have been adopting the device of contracts to

132. $\$ \$ 9-313,9-314$, and 9-315.

133. $\$ 9-401$. 
protect themselves against losses which might occur in the collection process. These fine print provisions placed on deposit slips, savings account books, notes and other forms used by the bank usually provide that the transaction involved is carried on in the risk of the consumer and that the bank is to be free of any resulting liability even for its own negligence. The courts have often cast a jaundiced eye upon these agreements but the law concerning their effectiveness has long been in a state of confusion. The Uniform Laws Commission has from time to time struggled with the problem of creating a uniform bank collections code. At one time they prepared such a statute but it failed of approval in the Commission itself because of opposition by the banks and their counsel. While the preliminary discussion of this process was still going on in the Uniform Laws Commission, the American Bankers Associntion through its counsel drafted a law covering the bank collection process designed to protect the banks throughout the process of collection, throwing the loss on the customers while giving the banks the rights of holders of clue course in the paper involved. ${ }^{134}$ This was dressed up under the deceiving title of the Uniform Bank Collections Code and was sold by the banking lobby to about nineteen legislatures ${ }^{\mathbf{1 3 5}}$ meeting over a period of about two years, who seemed to have adopted it under the mis-apprehension that it was a product of the Uniform Laws Commission. Thereafter, a number of atthorities in the field of banking and negotiable instruments wrote articles exposing the true nature of this so-called collections code and adoptions by the legislatures thereafter practically ceased. ${ }^{136}$

The act has been declared unconstitutional in whole ${ }^{137}$ or in part ${ }^{138}$ by the courts of a number of states. The result is continuing confusion. About twenty-seven states have the common law or fragmentary adoptions on the subject, the rest have the American Bankers Association Bank Collections Code or something like it. It may be unconstitutional in whole or in part. Not a very pretty picture.

The draftsman of the Commercial Code realized this situation and set out to produce a uniform act fair to both the bankers and the customer to remove the confusion in this field. Mr. Leary, the original draftsman of this article, after careful research into banking and clearing house practices and the current machinery of collection, attempted to devise a code which would fairly

134. This history is set out in detail by Wilson, 30 ORE. L. REv. 359 (1951).

135. See note 16, supra Beutet, BaNK OfFicers HandBooK 96 (1939).

136. Townsend, The Bank Collections Code, 8 Tulane L. Rev. 21, 236, 376 (1934); Steffen, The Check Collection Muddle, 10 id. 537 (1936); Beutel, The Proposed Uniform Bank Collections Act, 9 id. 378, 385 (1935); Donley, Some Problems of Collection of Checks, 38 W. VA. L. Q. 195 (1932); but see Bogert, Failed Bantss, Collection Items and Trust Preferences, 29 Mich. L. REv. 545, 567 (1931).

137. People ex rel. Barrett v. Union Bank, 362 Ill. 164, 199 N.E. 272 (1935).

138. See Note, 104 A.L.R, 1095 and authorities there cited and later supplementary notes. 
state the obligation of the banks to their customers and properly distribute liability and risk of loss. By May of 1951 this draft ${ }^{130}$ had almost reached the final stage but it was met by the unanimous opposition of the American Banker's Association and counsel and lobbyists who were constantly in attendance at the joint meetings of the Uniform Laws Commission and the American Law Institute. The result of the pressure was so great that in Mray, 1951 it was decided to omit Article 4 on Bank Collections for the Uniform Commerical Code, and to recommend the "Code" without it. Mr. Leary, with his ideas of fairness, was thus effectively side-tracked. The reduced "Code" was then finally adopted subject only to minor changes before the meeting of the American Bar Association in September of the same year. During the following summer months there occurred frenzied activity on the part of the bankers and their counsel with the result that late in August before the fall meeting of the Commissioners on Uniform Laws and the American Law Institute in connection with the American Bar Association there appeared a completely revised Article 4 in fragmentary form ${ }^{180}$ which was mailed to members of the Institute and the Commission giving them less than three weeks time to examine it before the meeting. ${ }^{141}$ It was then rushed through the final joint meeting with little or no debate and was approved by the Commissioners, the American Law Institute and the American Bar Association at the same time. It is fair to say that the great majority of the members of these organizations and those at the meeting had not even read the complete new Article $4^{142}$ and that ninety percent of the entire membership had no knowledge of its nature. Shocking as this seems, it was the usual procedure by which the draftsmen had been presenting the "Code" to the Institute and Commissioners, ${ }^{143}$ only in this instance their own technique was used against them.

This new Article 4 on Bank Deposits and Collections foilows very closely the already discredited American Banker's Association Uniform Bank Collection Code. ${ }^{144}$ It even re-enacts the preference articles which have caused that act to be held unconstitutional and which are admittedly contrary to cur-

139. See Uniforar Commerctal Code, Article 4 (September Revisions 19:0).

140. See August 1951 Revision of Article 4 (Mimeographed).

141. The covering letter from the Philadelphia office of the Institute was dated August 24. The final meeting was September 15, 1951.

142. A complete text of this new Article 4 was later published under the date September 3, 1951, superseding the August Revision. This article was still later changed in at least seven places further to favor the banks; cf. $\$ \$ 4-103(2)(3), 4-205(2), 4-207(1)$, 4-213(3), 4-301(4), 4-403(3), 4-407 in the September 3rd edition and the Final Test Edition.

143. See Beutel, The Proposed Unifomm Commercial Code, 16 Law \& Contrasp. PROR. 141, 142 (1951).

144. See explanation of Principal Changes in August Revision, sipra, note 140, $\$ \S 4-103,4-202,4-213,4-214$. 
rent federal legislation and not, therefore, applicable to National Banks. 146 However, it goes much further than the American Banker's Association Act in that it provides that all paper deposited with the bank, unless the contracts indicate otherwise, is left for collection ${ }^{140}$ and is to be handled entirely at the risk of the customer. ${ }^{147}$ The bank, on the other hand, has all the rights of a holder in due coirse when it is in any danger of suffering loss. ${ }^{148} \mathrm{All}$ liability of the bank for improper handling of paper so carefully and fairly set up in the earlier drafts ${ }^{149}$ is removed. ${ }^{100}$ By a trick provision of Section 4-103 and sub-section $4,{ }^{151}$ the bank is not bound to follow any of the collection procedures set out in the act. So long as it acts "reasonably," it is only liable for its own lack of good faith and due care;162 but even clue care is limited by other provisions of the "Code";153 and it is not liable for the acts of any of its agent or associate banks. ${ }^{154}$ Damages for the lack of due care and bad faith are carefully held to the minimum; $;^{165}$ and any action authorized by this Article is specifically made due, care for which the bank is not liable. ${ }^{150}$

145. §4-214; cf. A.B.A. code provision, Ilt. Rev. Stat. c. 16a §37(3) (Cahill 1931), declared unconstitutional in People ex, rel. Barrett, supra note 137; and Explanation of Principal Changes, August Revision supra note 140, §4-214.

146. \$4201: Unless a contrary intent clearly appears, a depositary bank takes an item for collection regardless of the form of indorsement or lack of indorsement and even though credit for the item is subject to immediate withdrawal as of right.

But see $\$ 4105$ (a). Unless $\$ 4-201$ covers all business it is meaningless. See Comment to $\$ 4-201$ (December Revision 1951). The A.B.A. Code was ambiguous on this point, see Illinois Act, supra note 144, §26.

147. $\S 4-211(1), \S 4-212$.

148. $\$ 4-209, \$ 4208$ supra note 31 .

149. $\$ \$ 4-109$, 4-103 (September Revison 1950).

150. See $\$ 4-103$ (August 1951 draft), Explanation of Principal Changes.

151. $\$ 4-103(4)$ : The specification or approval of certain procedures by this Article does not preclude an agreement authorized by sub-section (1), nor constitute disapproval of other procedures which may be reasonable under the circumstances.

152. $\$ 4-103(1)$ : The effect of the provisions of this Article may be varied by gcucral or special agreement except that no agreement can disclaim a bank's responsibility or limit the measure of damages for its own lack of good faith or failure to excrcise ordinary care.

153. $\$ 4103(3)$ : Action or non action approved by this Article or pussuant to a general agreement, or, in the the absence of special instructions, consistent with $a$ bank:ing usage, is ordinary care.

See $\S \S 4-108,4-202(2), 4-203,4-205(2), 4-210,4-211$.

154. \$4-202(1): A collecting bank must use ordinary care in

(a) presenting an item or sending it for presentment; and ...

(3) Subject to subsection (1) (a), a bank is not liable for the insolvency, neglect, misconduct, mistake or default of another bank.

See $\$ \S 4-106,4-102(2)$.

155. $\$ \$ 4-103(2), 4-202(3)$ supra note $154,4-212(5), 4-402,4-403(3), 4-404,4-405$, 4-407.

156. $\$ 4-103(3)$ sitpra note 153. 
Among the more striking of the acts authorized on the part of the banl: are the following. The bank is not bound to any notice from anybody except the person depositing the paper and need only follow his instructions. 157 The whole concept of payment in due course is abolished. ${ }^{168}$ The bank can pay a known thief of properly endorsed paper without any liability and there is nothing the true owner can do about it except bring an injunction "or supply indemnity deemed adequate" by the bank. ${ }^{159}$ There is grave doubt as to whether a law suit would do the true owner any good under the circumstances because the bank is allowed to supply indorsements of customers, ${ }^{160}$ and is specifically protected against any form of notice of agency or trust which may appear on the face of the paper or indorsements. ${ }^{101}$ The banl may also change by contract any of the rules set out in this act except the duty of due care. ${ }^{162}$ Thus the "Code" appears to completely approve the type of surreptitious waivers consistently appearing in fine print on bank forms, in spite of the fact that many courts have refused to enforce "contracts" of this kind. Article 4 and the definitions of contracts found in the "Code" give them blanket approval. ${ }^{163}$

A careful examination of the wording of the act will show that this Article was drafted entirely with the purpose of protecting the banks so that they could carry on their business at the risk of the customer. In most instances they have succeeded, with the aid of their lawyers, in shifting many of the risks of the banking business to their customers, where fairness in bank collections would require that the bank be the insurer of the paper which it is to collect. A few examples will show the complete one-sidedness of the "Code." Although the bank is supposed to be the agent of its customers for all paper placed in its custody by the customer either for deposit or collection, ${ }^{104}$ the "Code" sets out specifically and in minute detail the warranties which the customer makes to the bank by the transfer of such paper. ${ }^{105}$ But where the bank takes proceeds of the collection process on behalf of its customer no such warranties are required from the banker. On the contrary, it holds such paper to be collected at the risk of the customer. ${ }^{160}$ Where the bank: returns statements to the customer he must, at his peril, examine the statements not only for accuracy of signatures and alterations but also endorse-

157. \$4-203: Only a bank's transferor can give instructions which affect the bonk or constitute sotice to it and a bank is not liable to prior parties for any action talsen pursuant to such instructions or in accordance with any agresment with its transferor.

158. $\$ \$ 4-203$ supra note $157,3-603$.

159. $\$ 3-603(1)$.

160. $\$ 4-205(1)$.

161. $\$ 4-205(2)$.

162. \$4-103(1) supra note 152.

163. Ibid. And see definition of Agreement and Contract $\$ 1-201(3)$ and (11).

164. \$4-201 supra note 146 .

165. $\$ 4-207$.

166. $\$ 4-211$. See $\$ 4-212$. 
ments; and failure to turn up defects such as forgeries and the like in endorsements within the prescribed time throws the loss on the customer even though information of this kind is wholly within the knowledge of the banker and beyond the reach of the customer. ${ }^{107}$

An extreme example of this one-sided draftsmanship is shown in the duties and liabilities surrounding stop-payment as here codified. The customer still has the right to stop payment if he does so in the proper form, ${ }^{108}$ but the banker's liability for wrongfully ignoring stop payment is carefully limited to the actual loss caused thereby. ${ }^{109}$ And though the "Code" does not bother to state the customers' rights, it specifically provides conditions under which the bank can sue the customer when it has wrongfully ignored a stop payment order!170 In fact, this Article is so one-sidedly drawn in favor of the banking interests that any banker who insisted on exercising the rights given him by this "Code" would probably be under suspicion by the better business bureau.

This article is a deliberate sell-out of the American Law Institute and the Commission of Uniform Laws to the bank lobby in return for their support of the rest of the "Code." That this would happen was forecast in the debate before the Institute two years ago when Mr. Schnader in a discussion with the writer said that it would be necessary to make certain concessions to the banking interests in order to get their support for the "Code." And it is significant that Mr. Schnader, ${ }^{171}$ was very active in pushing the present article through the meeting of the Commissioners and the Institute in September even over the apparent protest of the Editor-in-Chief himself. They not only made concessions to the bankers but delivered everything they asked for. The banks now have a piece of class legislation more favorable to their interests than the American Bankers Association Bank Collections Code

167. $\$ 4-406$, especially sub-section $(1, c)$.

168. $\S \S 4-403,4-303$.

169. $\$ 4-103(2)$. See $\$ \$ 4-402,4-403(3)$.

170. \$4-407: Bank's Right to Subrogation on Improper Payment

To prevent unjust enrichment, a bank which has paid a customer's item which it may not charge in full to his account may in an action

(a) against a prior holder who has received the payment, recover any part thereof due to its customer or any prior party in respect of the transaction in which the customer of the depository bank acquired the item; and

(b) against the drawer, maker or acceptor recover any amount which would have been due from him on the item if payment had been refused.

The bank has no right to charge the customer's account in respect of such cause of action. The bank may bring either or both such actions but may have only one satisfaction and any right to consequential or punitative damages remains with the customer or holder.

171. First Vice-President of the American Law Institute, see the letter head of the Institute; Member of the Editorial Board for the "Code"; see Proposed Final Draft p. 3 (Spring 1950) ; long time counsel for Banks, see I Martindale 1267 (1937); and close associate of bankers, see Who's Who IN AMERICA 2086 (1946-47). 
which their lobby failed to put over on the legislatures. This one-sided piece of class legislation is now backed by the prestige of the American Law Institute and the Commission on Uniform Laws. Such a sell-out is beneath the dignity of both organizations and is a tremendous blow to their prestige as scientific bodies. It is doubtful if the majority of the members would have approved this article if they had known what they were doing; and, if they do so approve, it raises the question whether the American Law Institute has ceased to be a learned scientific body to become a plush pressure group dominated by reactionary financial interests. The existence of Article 4 alone is enough to condemn in its entirety the adoption of this "Code."

\section{ConcLusion}

The experience of the learned bodies sponsoring the "Code" with Article 4 shows the danger of having distinguished lawyers and judges in brief convention assembled or professors in their spare time pass upon and draft complicated commercial legislation. A project of the proportions and wide-spread effect of the Uniform Commercial Code should be supported by full time, deep and thorough economic and legal research by the best minds in the field. It can not be accomplished by the "Let George do it" atmosphere which prevails at the average American convention and which has, unfortunately, crept into the proceedings of the American Law Institute and the Commissioners on Uniform Laws.

On the whole the repeal of the seven current uniform laws and the adoption of this so-called "Code" can serve no purpose except by its complication and displacement of the law to create unnecessary business for the lawyers and the courts. Uniform Commercial Code is a misnomer; it should be called the Lawyers and Bankers Relief Act. If the "Code" in its present form is pushed through the New York Legislature by its high sounding backers, the Act will mark the beginning of the end of fairness and uniformity in the commercial law. 